\title{
Diet and Feeding Habits of Cyprinus carpio in Relation with Water Quality of Integrated Rice-Fish Farming Ecosystem
}

\author{
Md. Mostafizur Rahman Mondol ${ }^{{ }^{*} \text {, Md. Mosaddequr Rahman }}{ }^{1}$, Dil Afroz Nahar ${ }^{1}$, \\ Ferdous Ahamed ${ }^{2}$, Md. Al-Amin Sarker ${ }^{1}$, Bharat Raj Subba ${ }^{3}$, and Md. Yeamin \\ Hossain $^{1}$ \\ ${ }^{1}$ Department of Fisheries, Faculty of Agriculture, University of Rajshahi, Rajshahi-6205, Bangladesh \\ ${ }^{2}$ Department of Fisheries Management, Faculty of Fisheries, Patuakhali Science and Technology University, \\ Patuakhali 8602, Bangladesh \\ ${ }^{3}$ Department of Zoology, Post Graduate Campus (TU), Biratnagar, Nepal \\ *E-mail: mostafiz_bau@yahoo.com,mostafiz@ru.ac.bd
}

Received: 08.06.2013; Accepted: 21.09.2013

\begin{abstract}
This study describes the diets and feeding habits of Cyprinus carpio in integrated rice-fish farming system in the Agronomy Field Laboratory of Bangladesh Agricultural University, Mymensingh, Central Bangladesh during May 1999 to August 1999. Percentage of frequency of occurrence and percentage in number methods were applied for the qualitative and quantitative estimation of plankton. The water quality parameters recorded during the study were within the suitable range for optimal fish growth and plankton populations were also abundant in the water of the rice plots. The phytoplankton population recorded from the gut contents of $C$. carpio was under 4 groups (viz., Chlorophyceae, Euglenophyceae, Cyanophyceae, Bacillariophyceae) and the zooplankton under 3 groups (viz., Rotifera, Cladocera, Copepoda). Bacillariophyceae and Chlorophyceae were the dominant phytoplankton group while Rotifera was the dominant zooplankton group in the gut contents of $C$. carpio. This study also revealed that, gut contents of C. carpio was composed of $48.47 \%$ phytoplankton and $51.53 \%$ zooplankton indicating omnivorous nature of the fish. The availability of plankton population in the rice plots and the food and feeding habits of $C$. carpio suggest that, this fish could be a vital candidate for integrated rice-fish aquaculture.
\end{abstract}

Key words: Cyprinus carpio, food habits, gut contents, Integrated Rice-Fish Aquaculture, Bangladesh

\section{Introduction}

The common carp, Cyprinus carpio (Linnaeus, 1758) is widely distributed in Europe to Asia: Black, Caspian and Aral Sea basins. Though wild stocks of the common carp are present naturally only in rivers draining to the Black, Caspian and Aral Sea (Kottelat and Freyhof, 2007), this species is introduced throughout the world. Adults of $C$. carpio inhabit warm, deep, slow-flowing and still waters such as lowland rivers and large, well vegetated lakes (Kottelat and Freyhof, 2007). The common carp is usually hardy and tolerant to a wide variety of conditions but generally favors large water bodies with slow flowing or standing water and soft bottom sediments (Scott and Crossman, 1973). C. carpio spawns along shores or in backwaters and 
Md. Mostafizur Rahman Mondol, Md. Mosaddequr Rahman, Dil Afroz Nahar, Ferdous Ahamed, Md. Al-Amin Sarker, Bharat Raj Subba, and Md. Yeamin Hossain/ Our Nature (2013), 11(2): 138-151

frequently undertake considerable spawning migration to suitable backwaters and flooded meadows. However, for the survival of larvae warm water among shallow submerged vegetation is needed. The common carp mainly feeds on a variety of benthic organisms and plant material (Froese and Pauly, 2012) and is one of the few species that are favored for integrated rice-fish farming in the Asian countries.

Integrated rice-fish production can optimize resource utilization through the complementary use of land and water (Frei and Becker, 2005). Additionally, integration of fish with rice farming improves diversification, intensification, productivity, profitability, and sustainability (Ahmed et al., 2007; Nhan et al., 2007). In spite of a few constrains (labour cost, risk, uncertainty of rainfall and limited irrigation water, flood etc.), rice-fish culture can actually increase rice yields (up to $10 \%$ in some cases) while providing farmers with an important source of protein and extra income. The feeding behavior of fish in rice fields causes aeration of the water. Integrated rice-fish farming is also being regarded as an important element of integrated pest management (IPM) in rice crops (Berg, 2001; Halwart and Gupta, 2004). In addition, fish play a significant role in controlling aquatic weeds and algae that carry diseases, act as hosts for pests and compete with rice for nutrients. Moreover, fish eat flies, snails and insects, and can help to control malaria mosquitoes and water-borne diseases (Matteson, 2000). Interactions of fish and rice also help lower production costs because insects and pests are consumed by the fish. Shading by rice plants also maintains the water temperature favorable to fish during the summer (Kunda et al., 2008).

To know the biological aspects especially the food and feeding habits of fish is essential before selecting species for sustainable integrated rice-fish farming (Mondol et al., 2013). Yet no detail studies on the feeding ecology of $C$. carpio in ricefish farming are available in the literature. Thereby this study furnishes the first comprehensive study on the diets and feeding habits of the common carp in relation with the water quality parameters in integrated rice-fish farming systems, Mymensingh, central Bangladesh.

\section{Materials and methods \\ Experimental design and land preparation}

The present investigation was conducted in the Agronomy field laboratory, Bangladesh Agricultural University, Mymensingh $\left(24^{\circ} 75^{\prime} \mathrm{N}, 90^{\circ} 50^{\prime} \mathrm{E}\right)$, Bangladesh from May 1999 to August 1999. The experimental site was selected in a comparatively low land area within the deep tube-well irrigation facilities and consists of 2 experimental plots each with an area of 0.02 ha. Small water channels $(0.70 \mathrm{~m} \mathrm{X} 0.30 \mathrm{~m})$ were made between the plots to ensure water supply to the plots from deep tube-well. A $0.70 \mathrm{~m}$ high and $0.50 \mathrm{~m}$ wide embankment encircling the experimental plots were made to keep the plots free from flood during heavy rainfall. Additionally, one common inlet and outlet was provided on the dykes of each plot to control water depth and bamboo poles were placed to prevent invasion of wild fish and escape of stocked fish. The land was ploughed properly with power tiller and country plough and then leveled properly by laddering to keep even 
Md. Mostafizur Rahman Mondol, Md. Mosaddequr Rahman, Dil Afroz Nahar, Ferdous Ahamed, Md. Al-Amin Sarker, Bharat Raj Subba, and Md. Yeamin Hossain/ Our Nature (2013), 11(2): 138-151

water depth throughout the plots. To offer refuge to the stocked fish during high water temperature and low water level, a small ditch and a trench connecting the ditch were constructed in each plot. The area of each ditch was $4 \mathrm{~m}^{2}$ with a depth of about $70 \mathrm{~cm}$. The width and depth of the trenches were 40 $\mathrm{cm}$ and $30 \mathrm{~cm}$, respectively which were almost similar to the commonly practiced rice-fish farming in Indonesia (De la Cruz, 1992) and Bangladesh (Mazid et al., 1992).

\section{Fertilization}

Fertilization in the rice plots were done with urea, triple super phosphate (TSP), muriate of potash (MP) and gypsum at the rate of $200 \mathrm{~kg} / \mathrm{ha}, 150 \mathrm{~kg} / \mathrm{ha}, 75 \mathrm{~kg} / \mathrm{ha}$ and 166 $\mathrm{kg} / \mathrm{ha}$, respectively. All inorganic fertilizers except urea were applied evenly to the plots 2-3 days before transplanting the rice seedlings during the final ploughing and leveling. While urea was applied after 15, 55 and 70 days of transplanting rice seedlings with one third of total dose during each application.

\section{Transplantation of rice seedlings}

The high yielding variety of rice BR-2 having resistant power to insects and diseases was selected for this experiment. The rice seedlings were raised in an isolated seedbed near the experimental plots. Forty days old seedlings were uprooted carefully for transplantation in the experimental plots. Then the rice seedlings were transplanted on 18 May 1999 in alternate rows with spacing of $35 \mathrm{~cm}+15 \mathrm{~cm}$ according to Hossain et al. (1990).

\section{Stocking of fish fingerlings}

Fingerlings of $C$. carpio were stocked in the rice plots 20 days after transplantation of rice seedlings. In both the plots, fingerlings of $C$. carpio were stocked at a rate of $6000 /$ ha. For maintaining suitable water depth for fish in the rice plots, water was supplied regularly from the deep tube-well. During the study period no supplementary feed was provided for the fish.

\section{Monitoring of water quality parameters}

During the study period water temperature was recorded with a Celsius thermometer. Dissolved oxygen (DO) and $\mathrm{pH}$ were measured directly by using a digital electronic oxygen meter (YSI, Model 58) and $\mathrm{pH}$ meter (Jenway, Model 3020), respectively. Total alkalinity was determined using methyl orange indicator and standard EDTA solution by titrimetric method. These parameters were recorded weekly and the average values were noted each month. The concentration of nitratenitrogen $(\mathrm{mg} / 1)$ and phosphate-phosphorus $(\mathrm{mg} / 1)$ of water samples were determined in laboratory after filtering the water samples taken from each rich plot by using a spectrophotometer (Hack DR 2000) and reagent pillow nitrover and phosver-3. Chlorophyll $a(\mu \mathrm{g} / \mathrm{l})$ was measured from the filter paper (Whatman GF/C) used for filtering the water samples. The filter paper was dissolved in $10 \mathrm{ml}$ acetone and made ready for the analysis of chlorophyll $a$. Later chlorophyll $a$ was determined by using a spectrophotometer (Milton and Roy Spectronic, Model 1001) at 664 and $750 \mathrm{~nm}$ wavelengths. These parameters were recorded fortnightly and then average values were noted for each month.

\section{Plankton study from the water sample}

Ten liters of water sample were collected fortnightly from different areas and depth of 
Md. Mostafizur Rahman Mondol, Md. Mosaddequr Rahman, Dil Afroz Nahar, Ferdous Ahamed, Md. Al-Amin Sarker, Bharat Raj Subba, and Md. Yeamin Hossain/ Our Nature (2013), 11(2): 138-151

the water of the rice plots and passed through fine meshed $(25 \mu \mathrm{m})$ plankton net. Filtered samples were taken in a measuring cylinder and carefully made up to a standard volume of $50 \mathrm{ml}$. Then the collected plankton samples were preserved in 5\% buffered formalin solution in small plastic vials for subsequent studies. From each 50 $\mathrm{ml}$ preserved sample, $1 \mathrm{ml}$ sub-sample was examined using a Sedge-wick-Rafter cell (S-R-cell) under a binocular microscope (Olympus, Model B-2, with phase contrast facilities). The counting chamber of the S$\mathrm{R}$-cell is equally divided into 1000 fields each having a volume of $0.001 \mathrm{ml}$. Ten square fields of the S-R-cell chosen randomly and all planktonic organisms of these fields were counted and expressed numerically as per liter of water. Calculation of plankton samples was done by using the formula of Stirling (1985) as: $\mathrm{N}=\left(\mathrm{A}^{*} 1000^{*} \mathrm{C}\right) /\left(\mathrm{V}^{*} \mathrm{~F}^{*} \mathrm{~L}\right)$, where, $\mathrm{N}$ is the number of plankton cells or units per liter of original water; $\mathrm{A}$ is the total number of plankton counted; $\mathrm{C}$ is the volume of final concentrate of the samples in $\mathrm{ml} ; \mathrm{V}$ is the volume of field in cubic $\mathrm{ml}$; $\mathrm{F}$ is the number of fields counted and $\mathrm{L}$ is the volume of original water in liter.

\section{Plankton study from the gut content of fishes}

Thirty fishes were sampled fortnightly from the plots during study to determine the food and feeding habits. Immediately after sampling the fishes were preserved in $10 \%$ formalin solution. Then the stomach of each fish was dissected out and the contents of it were removed very carefully on Petridish. Only the anterior portion of the digestive tract lying between the oesophagus and the first major curve of the small intestine of entire gut was taken for this investigation (McComish, 1967; McKehnie and Penner, 1971; Dewan, 1973). Food contents of the gut were diluted in $5 \mathrm{ml}$ distilled water. $1 \mathrm{ml}$ sub-sample was transferred by a pipette to an S-R-cell. Ten fields out of 1000 fields of the counting cell were counted and multiplied by 500 to get the total number of plankton in the gut. By using a binocular microscope all organisms were counted and identified up to genus level. Then the occurrence of each and every food item in the individual gut was noted. The gut contents were analyzed using the following methods:

- Occurrence method (Hynes, 1950): where the number of fish in which each food item occurred was listed as percentage of the total number of fish examined.

- Numerical method (Hynes, 1950): where the number of individuals of each food item were recorded and expressed as percentage of the total number of organisms found in all the fish examined.

\section{Results \\ Water quality parameters in rice plots}

Monthly values of the water quality parameters including water temperature, dissolved oxygen (DO), $\mathrm{pH}$, total alkalinity, chlorophyll $a$, nitrate-nitrogen and phosphate-phosphorus are given in table 1 . The water temperature ranged from $27.20^{\circ} \mathrm{C}$ to $28.10^{\circ} \mathrm{C}$, dissolved oxygen from 3.99 $\mathrm{mg} / 1$ to $4.20 \mathrm{mg} / 1, \mathrm{pH}$ from 6.22 to 6.78 , total alkalinity from $25 \mathrm{mg} / 1$ to $83 \mathrm{mg} / 1$, chlorophyll $a$ from $12.66 \mu \mathrm{g} / 1$ to 24.80 $\mu \mathrm{g} / 1$, nitrate-nitrogen from $1.56 \mathrm{mg} / 1$ to $2.30 \mathrm{mg} / 1$ and phosphate-phosphorus 
Md. Mostafizur Rahman Mondol, Md. Mosaddequr Rahman, Dil Afroz Nahar, Ferdous Ahamed, Md. Al-Amin Sarker, Bharat Raj Subba, and Md. Yeamin Hossain/ Our Nature (2013), 11(2): 138-151

contents from $0.14 \mathrm{mg} / 1$ to $0.81 \mathrm{mg} / 1$ during the study period.

\section{Plankton population in the water of rice field}

The plankton populations in the water of rice fields were identified up to genus level and enumerated (Tab. 2). The phytoplankton populations recorded were divided into 4 broad groups viz., Chlorophyceae, Euglenophyceae, Cyanophyceae and Bacillariophyceae. A total of 37 genera of phytoplankton were recorded of which 19 belongs to Chlorophyceae, 2 to Euglenophyceae, 8 each to Cyanophyceae and Bacillariophyceae. A total of 12 genera of zooplankton were recorded in the rice field belongs to Rotifera, Cladocera and Copepoda (Tab. 2).

Among the phytoplankton populations Chlorophyceae was found to be the most dominant food group $\left(5.1 \times 10^{3}\right.$ cells/ 1 in number and $41.33 \%$ by percentage in number) followed by Bacillariophyceae, cyanophyceae and Euglenophyceae. On the other hand, Rotifera was found to be the most dominant food group of zooplankton $\left(1.1 \times 10^{3}\right.$ cells/ 1 in number and $8.88 \%$ by percentages in number) followed by Cladocera and Copepoda in the rice plots' water plankton concentration (Tab. 3).

Generic abundance of phytoplankton population in the water of rice plot

The dominant genera of phytoplankton recorded in the water of the rice field were Ankistrodesmus (3.56\%), Zygnema (3.56\%), Ceratium (2.66\%) Scenedesmus (2.66\%), Chrysococcus (2.66\%), Tetraedron (2.67\%), Oedogonium (2.67\%), Ulothrix (2.67\%) under Chlorophyceae, Euglena (2.66\%) under Euglenophyceae, Anabaena (2.67\%) and Microcystis (2.67\%) under Cyanophyceae and Surirella (4.0\%), Fragilaria (3.56\%), Navicula $(2.67 \%)$ and Cyclotella (2.67\%) under Bacillariophyceae. The least dominant genera of phytoplankton were Micrasterium (0.88\%), Gonatogygon $(1.33 \%)$ and Spriogyra (1.33\%) under Chlorophyceae and Nitzschia (1.33\%) under Bacillariophyceae. Among the zooplankton the dominant genera were Brachionus (1.78\%), Asplanchna (1.78\%) and Notholca $(1.78 \%)$ under Rotifera, Diaphanosoma $(1.78 \%)$ and Moina $(1.78 \%)$ under Cladocera and Cyclops (1.78\%) and Diaphtomus (1.78\%) under Copepoda. Conversely, the least dominant genera of zooplankton were Keratella $(1.33 \%)$ and Trichocerca (1.33\%) under Cladocera and Nauplius (1.33\%) under Copepoda (Tab. 3).

\section{Plankton population in the gut contents of C. carpio}

The phytoplankton populations identified in the gut contents of $C$. carpio were also distributed in 4 groups namely Chlorophyceae, Euglenophyceae, Cyanophyceae and Bacillariophyceae (Tab. 4). Thirty two genera of phytoplankton recorded in the gut contents of $C$. carpio, of which 15 were Chlorophyceae, 2 Euglenophyceae, 8 Cyanophyceae and 8 Bacillariophyceae. Among the 4 groups of phytoplankton Bacillariophyceae was the most dominant group in the gut contents of $C$. carpio both by percentage in number (18.29\%) and percentage of frequency of occurrence (100\%) which was closely followed by Chlorophyceae $(17.23 \%$ in number and $100 \%$ in occurrence), Cyanophyceae and Euglenophyceae (Figs. 1 and 2). The 
Md. Mostafizur Rahman Mondol, Md. Mosaddequr Rahman, Dil Afroz Nahar, Ferdous Ahamed, Md. Al-Amin Sarker, Bharat Raj Subba, and Md. Yeamin Hossain/ Our Nature (2013), 11(2): 138-151

Table 1. Monthly variation (mean \pm SD) of water quality parameters recorded during June-August in rice plots, Mymensingh, central Bangladesh.

\begin{tabular}{lcccc}
\hline \multirow{2}{*}{ Parameters } & \multicolumn{3}{c}{ Monthly average values } & \multirow{2}{*}{ Range } \\
\cline { 2 - 4 } & June & July & August & \\
\hline Water temperature $\left({ }^{\circ} \mathrm{C}\right)$ & $27.80 \pm 0.07$ & $28.15 \pm 0.12$ & $27.60 \pm 0.24$ & $27.20-28.10$ \\
Dissolved oxygen $(\mathrm{mg} / \mathrm{l})$ & $4.10 \pm 0.06$ & $4.08 \pm 0.05$ & $4.12 \pm 0.09$ & $3.99-4.20$ \\
pH & $6.67 \pm 0.16$ & $6.99 \pm 0.09$ & $6.34 \pm 0.09$ & $6.22-6.78$ \\
Total alkalinity $(\mathrm{mg} / \mathrm{l})$ & $34.50 \pm 1.17$ & $31.17 \pm 5.09$ & $79.50 \pm 14.07$ & $25.0-83.0$ \\
Chlorophyll $a(\mu \mathrm{g} / \mathrm{l})$ & $13.20 \pm 1.61$ & $21.13 \pm 1.84$ & $15.33 \pm 2.55$ & $12.66-24.80$ \\
Nitrate-nitrogen $(\mathrm{mg} / \mathrm{l})$ & $1.63 \pm 0.06$ & $1.87 \pm 0.09$ & $1.93 \pm 0.10$ & $1.56-2.30$ \\
Phosphate-phosphorus $(\mathrm{mg} / \mathrm{l})$ & $0.56 \pm 0.06$ & $0.71 \pm 0.18$ & $0.35 \pm 0.03$ & $0.14-0.81$ \\
\hline
\end{tabular}

Table 2. List of genera of phytoplankton and zooplankton recorded during June-August in rice plots, Mymensingh, central Bangladesh.

\begin{tabular}{|c|c|c|}
\hline & Genera & Total \\
\hline \multicolumn{3}{|l|}{ Phytoplankton } \\
\hline Chlorophyceae & $\begin{array}{l}\text { Ankistrodesmus, Actinastrum, Ceratium, Chlorella, Chrysococcus, Closterium, } \\
\text { Coelastrum, Cosmerium, Gloeocystis, Scenedesmus, Micrasterium, Gonatogygon, } \\
\text { Pediastrum, Tetraedron, Volvox, Spirogyra, Zygnema, Oedogonium, Ulothrix }\end{array}$ & 19 \\
\hline Euglenophyceae & Euglena, Phacus & 2 \\
\hline Cyanophyceae & $\begin{array}{l}\text { Anabaena, Aphanocapsa, Gloeotrichia, Gomphosphaeria, Microcystis, Oscillatoria, } \\
\text { Gloeocapsa, Aphanizomenon }\end{array}$ & 8 \\
\hline Bacillariophyceae & $\begin{array}{l}\text { Cyclotella, Fragilaria, Frustularia, Navicula, Surirella, Tabellaria, Nitzschia, } \\
\text { Melosira }\end{array}$ & 8 \\
\hline \multicolumn{2}{|c|}{ Total Phytoplankton } & 37 \\
\hline \multicolumn{3}{|l|}{ Zooplankton } \\
\hline Rotifera & Asplanchna, Brachionus, Keratella, Polyarthra, Trichocerca, Notholca & 6 \\
\hline Cladocera & Daphnia, Diaphanosoma, Moina & 3 \\
\hline Copepoda & Cyclops, Diaptomus, Nauplius & 3 \\
\hline \multicolumn{2}{|l|}{ Total Zooplankton } & 12 \\
\hline
\end{tabular}

Table 3. Composition of different food items recorded during June-August in rice plots, Mymensingh, central Bangladesh.

\begin{tabular}{|c|c|c|c|}
\hline \multicolumn{2}{|c|}{ Food items } & \multirow{3}{*}{$\begin{array}{c}\text { Average in number } \\
444.44\end{array}$} & \multirow{2}{*}{$\%$ in number } \\
\hline Phytoplankton & & & \\
\hline Chlorophyceae & Ankistrodesmus & & 3.56 \\
\hline & Actinastrum & 222.22 & 1.78 \\
\hline & Ceratium & 333.33 & 2.66 \\
\hline & Chlorella & 222.22 & 1.78 \\
\hline & Chrysococcus & 333.33 & 2.66 \\
\hline & Closterium & 222.22 & 1.78 \\
\hline & Coelastrum & 222.22 & 1.78 \\
\hline & Cosmerium & 222.22 & 1.78 \\
\hline & Gloeocystis & 222.22 & 1.78 \\
\hline & Scenedesmus & 333.33 & 2.66 \\
\hline & Micrasterium & 111.11 & 0.88 \\
\hline & Gonatogygon & 166.66 & 1.33 \\
\hline
\end{tabular}


Md. Mostafizur Rahman Mondol, Md. Mosaddequr Rahman, Dil Afroz Nahar, Ferdous Ahamed, Md. Al-Amin Sarker, Bharat Raj Subba, and Md. Yeamin Hossain/ Our Nature (2013), 11(2): 138-151

\begin{tabular}{|c|c|c|c|}
\hline & Pediastrum & 277.77 & 2.22 \\
\hline & Tetraedron & 333.33 & 2.67 \\
\hline & Volvox & 222.22 & 1.78 \\
\hline & Spirogyra & 166.66 & 1.33 \\
\hline & Zygnema & 444.44 & 3.56 \\
\hline & Oedogonium & 333.33 & 2.67 \\
\hline & Ulothrix & 333.33 & 2.67 \\
\hline Total Chlorophyceae & & 5166.60 & 41.33 \\
\hline \multirow[t]{2}{*}{ Euglenophyceae } & Euglena & 333.33 & 2.66 \\
\hline & Phacus & 277.77 & 2.22 \\
\hline Total Euglenophyceae & & 611.10 & 4.88 \\
\hline \multirow{8}{*}{ Cyanophyceae } & Anabaena & 333.33 & 2.67 \\
\hline & Aphanocapsa & 166.66 & 1.33 \\
\hline & Gloeotrichia & 166.66 & 1.33 \\
\hline & Gomphosphaeria & 222.22 & 1.78 \\
\hline & Microcystis & 333.33 & 2.67 \\
\hline & Oscillatoria & 222.22 & 1.78 \\
\hline & Gloeocapsa & 277.7 & 2.22 \\
\hline & Aphanizomenon & 222.22 & 1.78 \\
\hline Total Cyanophyceae & & 1944.41 & 15.56 \\
\hline \multirow[t]{8}{*}{ Bacillariophyceae } & Cyclotella & 333.33 & 2.67 \\
\hline & Fragilaria & 444.44 & 3.56 \\
\hline & Frustularia & 222.22 & 1.78 \\
\hline & Navicula & 333.33 & 2.67 \\
\hline & Surirella & 500.00 & 4.00 \\
\hline & Tabellaria & 222.22 & 1.78 \\
\hline & Nitzschia & 166.66 & 1.33 \\
\hline & Melosira & 222.22 & 1.78 \\
\hline Total Bacillariophyceae & & 2444.42 & 19.57 \\
\hline Total phytoplankton & & 10166.53 & 81.34 \\
\hline \multicolumn{4}{|l|}{ Zooplankton } \\
\hline \multirow[t]{6}{*}{ Rotifera } & Asplanchna & 222.22 & 1.78 \\
\hline & Brachionus & 222.22 & 1.78 \\
\hline & Keratella & 166.66 & 1.33 \\
\hline & Polyarthra & 111.11 & 0.88 \\
\hline & Trichocerca & 166.66 & 1.33 \\
\hline & Notholca & 222.22 & 1.78 \\
\hline Total Rotifera & & 1111.09 & 8.88 \\
\hline \multirow[t]{3}{*}{ Cladocera } & Daphnia & 166.66 & 1.33 \\
\hline & Diaphanosoma & 222.22 & 1.78 \\
\hline & Moina & 222.22 & 1.78 \\
\hline Total Cladocera & & 611.11 & 4.89 \\
\hline \multirow[t]{3}{*}{ Copepoda } & Cyclops & 222.22 & 1.78 \\
\hline & Diaptomus & 222.22 & 1.78 \\
\hline & Nauplius & 166.66 & 1.33 \\
\hline \multicolumn{2}{|l|}{ Total Copepoda } & 611.11 & 4.89 \\
\hline \multicolumn{2}{|l|}{ Total Zooplankton } & 2333.31 & 18.66 \\
\hline
\end{tabular}


Md. Mostafizur Rahman Mondol, Md. Mosaddequr Rahman, Dil Afroz Nahar, Ferdous Ahamed, Md. Al-Amin Sarker, Bharat Raj Subba, and Md. Yeamin Hossain/ Our Nature (2013), 11(2): 138-151

Table 4. Generic status of different phytoplankton and zooplankton in the gut contents of Cyprinus carpio recorded during June-August in rice plots, Mymensingh, central Bangladesh.

\begin{tabular}{|c|c|c|}
\hline Food groups & Genera & Total \\
\hline \multicolumn{3}{|l|}{$\overline{\text { Phytoplankton }}$} \\
\hline Chlorophyceae & $\begin{array}{l}\text { Ankistrodesmus, Ceratium, Chlorella, Chrysococcus, Closterium, } \\
\text { Cosmerium, Scenedesmus, Micrasterium, Ocystis, Gonatogygon, } \\
\text { Tetraedron, Volvox, Zygnema, Oedogonium, Ulothrix }\end{array}$ & 15 \\
\hline Euglenophyceae & Euglena, Phacus & 2 \\
\hline Cyanophyceae & $\begin{array}{l}\text { Anabaena, Aphanocapsa, Gloeotrichia, Gomphosphaeria, } \\
\text { Merismopedia, Microcystis, Oscillatoria }\end{array}$ & 7 \\
\hline Bacillariophyceae & $\begin{array}{l}\text { Cyclotella, Fragilaria, Melosira, Navicula, Synedra, Surirella, } \\
\text { Tabellaria, Nitzschia }\end{array}$ & 8 \\
\hline Total phytoplankton & & 32 \\
\hline \multicolumn{3}{|l|}{ Zooplankton } \\
\hline Rotifera & Asplanchna, Brachionus, Keratella, Polyarthra, Trichocerca, Notholca & 6 \\
\hline Cladocera & Daphnia, Diaphanosoma, Moina & 3 \\
\hline Copepoda & Cyclops, Diaptomus, Nauplius & 3 \\
\hline Total zooplankton & & 12 \\
\hline
\end{tabular}

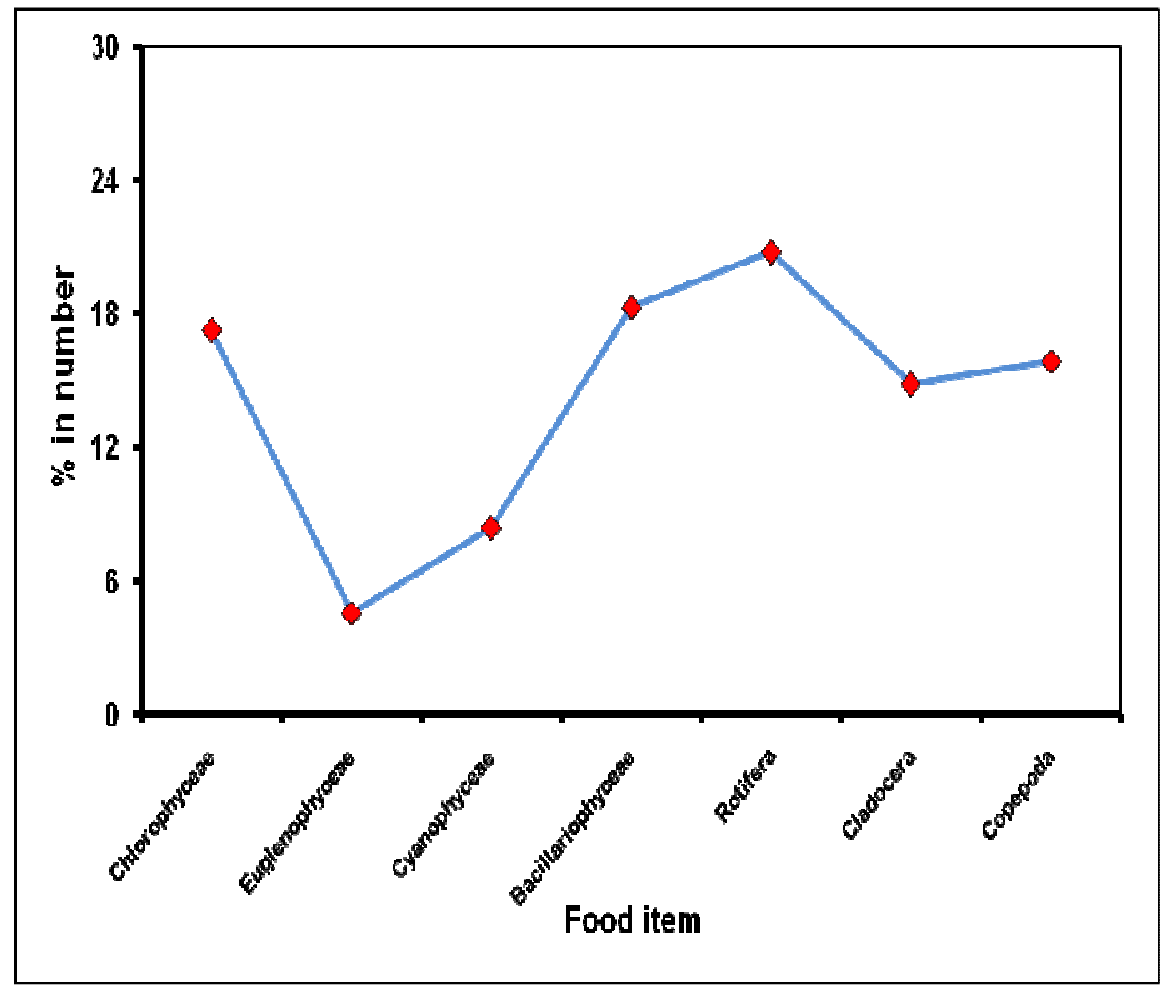

Figure 1. Composition (\% in number) of different food groups found in the gut contents of Cyprinus carpio recorded during June-August in rice plots, Mymensingh, central Bangladesh. 
Md. Mostafizur Rahman Mondol, Md. Mosaddequr Rahman, Dil Afroz Nahar, Ferdous Ahamed, Md. Al-Amin Sarker, Bharat Raj Subba, and Md. Yeamin Hossain/ Our Nature (2013), 11(2): 138-151

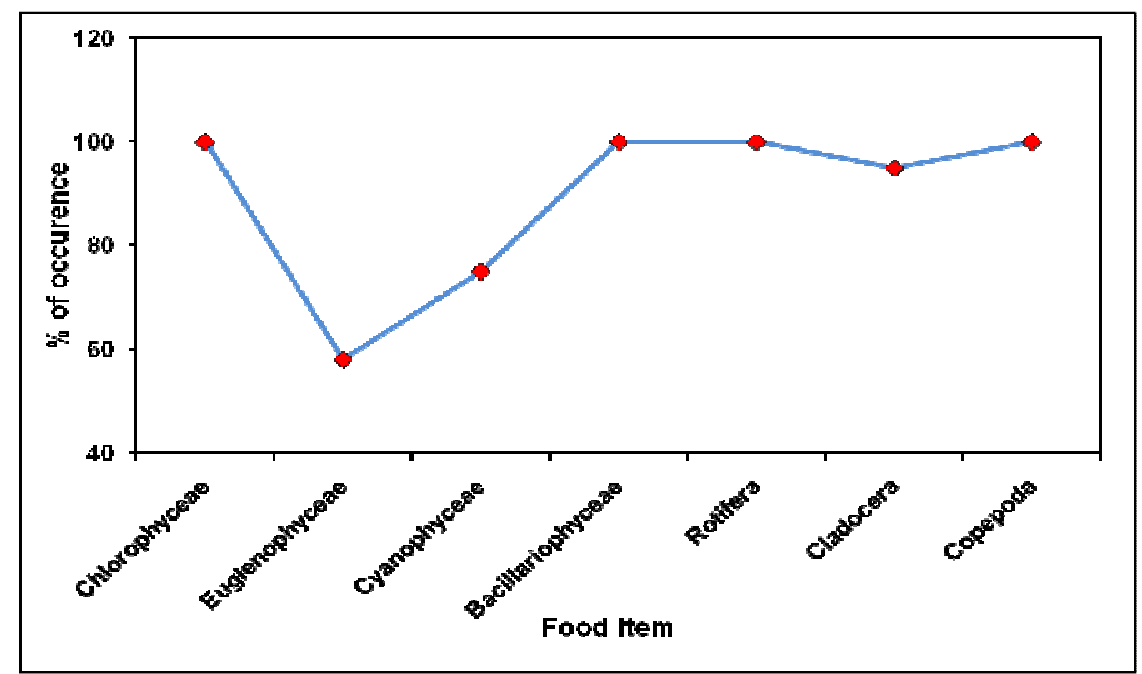

Figure 2. Percentage of occurrence of different plankton groups in the gut content of Cyprinus carpio recorded during June-August in rice plots, Mymensingh, central Bangladesh.

zooplankton population recorded in the gut contents was divided into 3 groups viz., Rotifera, Cladocera and Copepoda. A total of 12 genera of zooplankton were recorded in the gut contents of C. carpio of which 6 were Rotifera, 3 Cladocera and 3 Copepoda. Rotifera was the most dominant group in the gut contents of C. carpio $(20.79 \%$ in number and $100 \%$ in occurrence) which was closely followed by Cladocera and Copepoda (Figs. 1 and 2).

\section{Generic contribution of plankton} population in the gut contents of C. carpio

The generic contribution of plankton population in the gut contents were determined by percentage of frequency of occurrence and percentage in number and the results obtained are presented in table 5 . Among all the genera of phytoplankton Navicula was found to be the most dominant genus ( $85 \%$ by occurrence and $5.55 \%$ in number) (Tab. 5) followed by
Fragilaria, Tabellaria, Euglena, Chrysococcus, Oedogonium and Gomphosphaeria. On the other hand, among all the genera of zooplankton highest contribution to the gut contents of the fish was made by Cyclops both by percentage of frequency of occurrence $(85 \%)$ and by percentage in number $(8.19 \%)$ followed by Daphnia, Keratella, Moina, Polytarthra, Diaphanosoma, Brachionus, Diaptomus, Nauplius and Trichocerca (Tab. 5). However, the zooplankton population contributed higher proportion in the gut contents of C. carpio than that of phytoplankton.

\section{Relative abundance of food plankton in the} gut contents of $C$. carpio in relation to their availability in the water of rice plots

The relative abundance of different food items in the gut contents of C. carpio in relation to their availability in the water of rice plots were determined by percentage in number and is shown in the tables 3 and 5 . 
Md. Mostafizur Rahman Mondol, Md. Mosaddequr Rahman, Dil Afroz Nahar, Ferdous Ahamed, Md. Al-Amin Sarker, Bharat Raj Subba, and Md. Yeamin Hossain/ Our Nature (2013), 11(2): 138-151

Table 5. Composition of different food items in the gut contents of Cyprinus carpio by percentage in number and percentage of frequency of occurrence recorded during June-August in rice plots, Mymensingh, central Bangladesh.

\begin{tabular}{|c|c|c|c|}
\hline \multicolumn{2}{|c|}{ Food items } & \multirow{2}{*}{$\begin{array}{c}\% \text { in } \\
\text { number }\end{array}$} & \multirow{2}{*}{$\begin{array}{c}\% \text { of } \\
\text { occurrence }\end{array}$} \\
\hline Phytoplankton & & & \\
\hline \multirow[t]{15}{*}{ Chlorophyceae } & Ankistrodesmus & 0.93 & 12.5 \\
\hline & Ceratium & 0.14 & 2.5 \\
\hline & Chlorella & 1.07 & 37.5 \\
\hline & Chrysococcus & 3.56 & 55.0 \\
\hline & Closterium & 1.21 & 35.0 \\
\hline & Cosmerium & 1.43 & 40.0 \\
\hline & Scenedesmus & 1.07 & 20.0 \\
\hline & Micrasterium & 0.21 & 5.0 \\
\hline & Ocystis & 0.07 & 2.5 \\
\hline & Gonatogygon & 1.70 & 42.0 \\
\hline & Tetraedron & 0.42 & 10.0 \\
\hline & Volvox & 0.57 & 12.5 \\
\hline & Zygnema & 0.93 & 15.0 \\
\hline & Oedogonium & 2.71 & 47.5 \\
\hline & Ulothrix & 1.21 & 34.5 \\
\hline Total Chlorophyceae & & 17.23 & \\
\hline \multirow[t]{2}{*}{ Euglenophyceae } & Euglena & 3.7 & 52.5 \\
\hline & Phacus & 0.85 & 10.0 \\
\hline Total Euglenophyceae & & 4.55 & \\
\hline \multirow[t]{7}{*}{ Cyanophyceae } & Anabaena & 0.64 & 7.5 \\
\hline & Aphanocapsa & 0.42 & 7.5 \\
\hline & Gloeotrichia & 0.14 & 2.5 \\
\hline & Gomphosphaeria & 2.28 & 22.5 \\
\hline & Merismopedia & 0.71 & 7.5 \\
\hline & Microcystis & 0.64 & 12.5 \\
\hline & Oscillatoria & 3.57 & 37.5 \\
\hline Total Cyanophyceae & & 8.4 & \\
\hline \multirow[t]{8}{*}{ Bacillariophyceae } & Cyclotella & 0.71 & 17.5 \\
\hline & Fragilaria & 4.56 & 65.0 \\
\hline & Melosira & 0.21 & 2.5 \\
\hline & Navicula & 5.55 & 85.0 \\
\hline & Synedra & 1.0 & 17.5 \\
\hline & Surirella & 1.14 & 20.0 \\
\hline & Tabellaria & 4.48 & 62.5 \\
\hline & Nitzschia & 0.64 & 10.0 \\
\hline Total Bacillariophycea & & 18.29 & \\
\hline Total Phytoplankton & & 48.47 & \\
\hline \multicolumn{4}{|l|}{ Zooplankton } \\
\hline \multirow[t]{6}{*}{ Rotifera } & Asplanchna & 1.0 & 17.5 \\
\hline & Brachionus & 3.84 & 40.0 \\
\hline & Keratella & 7.2 & 60.0 \\
\hline & Polyarthra & 4.41 & 50.0 \\
\hline & Trichocerca & 3.7 & 37.5 \\
\hline & Notholca & 0.64 & 7.5 \\
\hline Total Rotifera & & 20.79 & \\
\hline
\end{tabular}


Md. Mostafizur Rahman Mondol, Md. Mosaddequr Rahman, Dil Afroz Nahar, Ferdous Ahamed, Md. Al-Amin Sarker, Bharat Raj Subba, and Md. Yeamin Hossain/ Our Nature (2013), 11(2): 138-151

\begin{tabular}{|c|c|c|c|}
\hline \multirow[t]{3}{*}{ Cladocera } & Daphnia & 6.12 & 75.0 \\
\hline & Diaphanosoma & 3.91 & 45.0 \\
\hline & Moina & 4.84 & 50.0 \\
\hline Total Cladocera & & 14.87 & \\
\hline \multirow{3}{*}{ Copepoda } & Cyclops & 8.19 & 85.0 \\
\hline & Diaptomus & 3.84 & 47.0 \\
\hline & Nauplius & 3.84 & 50.0 \\
\hline Total Copepoda & & 15.87 & \\
\hline Total zooplankton & & 51.53 & \\
\hline
\end{tabular}

Both in the water of rice plots and in the gut contents of C. carpio Chrysococcus, Oedogonium, Euglena, Oscillatoria, Gomphosphaeria, Fragilaria, Navicula and Tabellaria were found abundant among the genera of phytoplankton indicating that the fish preferred to feed on these genera. But Aphanizomenon, Frastularia, Actinastrum, Coelastrum and Spirogyra were not recorded in the gut contents of this fish though they were found to occur more or less abundantly in the water of rice plots which indicates that the fish did not prefer to feed on them. Among the genera of zooplankton Brachionus, Keratella, Polyarthra, Trichocera, Dophnia, Diaphanosoma, Moina and Cyclops were found to be dominant genera both in the gut contents and in the water of the rice fields indicating their preference in the food list of C. carpio.

\section{Discussion}

\section{Water quality parameters}

The water quality parameters logged during the study period were within the suitable range for optimal fish growth in integrated rice-fish farming. Water temperature of the rice plots' water was found to vary between $27.20^{\circ} \mathrm{C}$ and $28.10^{\circ} \mathrm{C}$ which is in accordance to those reported by Ali (1990) and Ghosh (1992).

On the other hand, dissolved oxygen was found to range from $3.99 \mathrm{mg} / 1$ to 4.20 $\mathrm{mg} / 1$ which is more or less similar to the findings reported by Ghosh (1992) and Uddin (1998) as $3.55 \mathrm{mg} / 1$ to $6.77 \mathrm{mg} / 1$ and $3.70 \mathrm{mg} / 1$ to $6.0 \mathrm{mg} / 1$, respectively in their study in the rice fields. Moreover, the present study found the $\mathrm{pH}$ to be fluctuated between 6.22 and 6.78 which is a bit lower than that obtained by Uddin (1998) as 7.3 in his experiment in rice-fish culture. Furthermore, in case of aquatic productivity, total alkalinity is another important factor. In this experiment, the total alkalinity values $(25 \mathrm{mg} / 1$ to $83 \mathrm{mg} / 1)$ recorded were more or less similar to the values $(25 \mathrm{mg} / 1$ to 100 $\mathrm{mg} / 1$ ) obtained by Uddin (1998) and was suitable for supporting optimal fish growth.

In addition, the concentration of chlorophyll $a$ ranged from $12.66 \mu \mathrm{g} / 1$ to $24.80 \mu \mathrm{g} / 1$ during present study which is nearly within the range described by Uddin (1998) and Ali (1990) as $14.70 \mu \mathrm{g} / 1$ to 55.0 $\mu \mathrm{g} / 1$ and $45.2 \mu \mathrm{g} / 1$, respectively in rice fields. However, the values of chlorophyll $a$ showed wide variations during the study period, which might be associated with the grazing pressure of fishes as well as water level fluctuation within the rice plots due to heavy rainfall.

Furthermore, the values of Nitratenitrogen $\left(\mathrm{NO}_{3}-\mathrm{N}\right)$ in the water of rice fields ranged between $1.56 \mathrm{mg} / 1$ and $2.30 \mathrm{mg} / 1$ during the study period which is within the range described by Ghosh (1992) as 0.02 
Md. Mostafizur Rahman Mondol, Md. Mosaddequr Rahman, Dil Afroz Nahar, Ferdous Ahamed, Md. Al-Amin Sarker, Bharat Raj Subba, and Md. Yeamin Hossain/ Our Nature (2013), 11(2): 138-151

$\mathrm{mg} / 1$ to $2.6 \mathrm{mg} / 1$ and Ali (1990) as 0.22 $\mathrm{mg} / 1$ to $2.30 \mathrm{mg} / 1$. However, Whitton et al. (1988) recorded the Nitrate-nitrogen as 0.006 to $0.05 \mathrm{mg} / 1$ which is far less than the values of the present study. Nonetheless, findings indicated that the water of rice plots in this study was highly productive (Alikunhi, 1957). Additionally, the values of Phosphate-Phosphorus $\left(\mathrm{PO}_{4}-\mathrm{P}\right)$ ranged from $0.14 \mathrm{mg} / 1$ to $0.51 \mathrm{mg} / 1$ which is much higher than those reported by Ghosh (1992) as $0.03 \mathrm{mg} / 1$ to $0.09 \mathrm{mg} / 1$ in his experiment on rice fish culture. Nevertheless, the higher values noted during this study may be due to the application of TSP in the rice plots.

\section{Plankton population in rice plots' water}

The phytoplankton population recorded in the present study was categorized into Chlorophyceae, Euglenophyceae, Cyanophyceae and Bacillariophyceae and zooplankton population into Rotifera, Cladocera and Copepoda. A total of 37 genera of phytoplankton and 12 genera of zooplankton were recorded. Dewan et al. (1991) identified 27 genera of phytoplankton belonging to Chlorophyceae, Cyanophyceae, Bacillariophyceae and Euglenophyceae and 9 genera of zooplankton belonging to Hydrozoa, Rotifera and Crustacea in their study which closely match the findings of the present study.

Among 4 groups of phytoplankton Chlorophyceae was the most dominant group which was closely followed by Bacillariophyceae while Euglenophyceae was the least dominant group. Sah et al. (1971) also recorded similar findings in their study. Among the groups of zooplankton Rotifera was found to be the most dominant group and Cladocera was the least dominant group. However, between the zooplankton and phytoplankton, phytoplankton was highly dominant over the zooplankton population in the rice plots' water. Similar results were found by Dewan (1973) and Chowdhury (1999) in their respective studies.

\section{Digestive tract contents and the food types}

In the present study, gut contents' analysis of $C$. carpio revealed gut composition was slightly dominated by zooplankton (51.53\%) over phytoplankton $48.47 \%$. Furthermore, the gut contents' analysis exposed 4 groups of phytoplankton (Chlorophyceae, Euglenophyceae, Cyanophyceae and Bacillariophyceae) and 3 groups of zooplankton (Rotifera, Cladocera and Copepoda). Among the food groups Bacillariophyceae and Chlorophyceae were almost equally dominant while Euglenophyceae was less preferred food groups of the common carp. On the other hand, Rotifera was found to be the most dominant zooplankton in the gut contents both by percentage in number and percentage of occurrence followed by Copepoda and Cladocera. Dewan et al. (1985) also reported similar findings in their study on the food and feeding habits of $C$. carpio. Manon and Hossain (2011) studied the food and feeding habits of $C$. carpio var. specularis and described the fish as omnivorous in nature, feeding mainly on zooplankton, debris and detritus, phytoplankton, aquatic plant parts, insects and semi-digested food materials. Present study also labels $C$. carpio as omnivore fish, feeding almost equally on phytoplankton and zooplankton. Thereby, this study 
Md. Mostafizur Rahman Mondol, Md. Mosaddequr Rahman, Dil Afroz Nahar, Ferdous Ahamed, Md. Al-Amin Sarker, Bharat Raj Subba, and Md. Yeamin Hossain/ Our Nature (2013), 11(2): 138-151

recommends $C$. carpio as a suitable option for selection for integrated rice-fish farming.

\section{Acknowledgements}

We would like to thank the Department of Fisheries Management, Faculty of Fisheries, Bangladesh Agricultural University, Bangladesh for laboratory facilities. Also, we express our gratitude to Global Fisheries Research Foundation (GFRF) for providing technical support during the preparation of this article.

\section{References}

Ahmed, N., M.A. Wahab and S.H. Thilsted 2007. Integrated aquaculture-agriculture systems in Bangladesh: potential for sustainable livelihoods and nutritional security of the rural poor. Aquaculture Asia 12(1): 14-22.

Ali, A.B. 1990. Rice fish farming in Malaysia: A resource optimization. AMBIO 19: 404-408.

Alikunhi, K.H. 1957. Fish culture in India. Farm. Bull. India Council Agric. Res. 20: 1-144.

Berg, H. 2001. Pesticide use in rice and rice-fish farms in the Mekong Delta, Vietnam. Crop Protection 20: 897-905.

Chowdhury, F.A. 1999. Effects of Hypopthalmichthys molitrix and Catla catla on the growth, survival and yields of Amblypharylgodon mola in mixed culture. Bangladesh Agricultural University, Mymensingh. 131p. (M.Sc. Thesis)

De la Cruz, R.C. 1992. Rice-fish culture in Indonesia. ICLARM and IRRI, Philippines. pp. 1-4.

Dewan, S. 1973. Investigations into the ecology of fishes of Mymensingh Lake. Bangladesh Agricultural University, Mymensingh, Bangladesh. (Ph.D. Thesis)

Dewan, S., M.A. Wahab, M.C.M. Beveridge, M.H. Rahman and B.K. Sarker 1991. Food selection, electivity and dietary overlap among planktivorous Chinese and Indian major carp fry and fingerlings grown in extensively managed, rainfed ponds in Bangladesh. Aquacult. Fish. Manage. 22: 277-294.

Dewan, S., M.J.U. Miah and M.N. Uddin 1985. Studies on the food and feeding habits of Cyprinus carpio. II. Diet and seasonal patterns of feeding of the fish. Bangladesh J. Aquacult. 6: 11-18.

Frei, M. and K. Becker 2005. Integrated rice-fish culture: coupled production saves resources. Natural Resources Forum 29: 135-143.

Froese, R. and D. Pauly (Eds) 2012. Fishbase 2013. Worldwide web electronic publication. Available at: http://www.fishbase.org (Accessed on 28 May, 2013).

Ghosh, A. 1992. Rice-fish farming development in India: Past, present and future. In Rice-Fish Research and Development in Aisa (Eds. C.R. De la-Cruz, C. Lightfoot, B.A. Costa-pierce, V.R. Carnagal and M.P. Bimbao). The Marine Science Institute, Manila, Philippines. pp. 27-43.

Halwart, M. and M.V. Gupta 2004. Culture of fish in rice fields. Food and Agriculture Organization of the United Nations and the World Fish Center. $83 p$.

Hossain, A., A. Hussain, F.A. Chaughtai and M. Butt 1990. Effects of Leucana and Sesbania leaf manuring on crop growth and physico-chemical properties of soil. Nitrogen Fix. Res. 43: 907-907.

Hynes, H.B.N. 1950. The food of freshwater stickle backs (Gasterosleus aculaetus and Pygosteus Pungitius), with a review of methods used in studied on the food of fishes. J. Anim. Ecol. 19: 36-48.

Kottelat, M. and J. Freyhof 2007. Handbook of European freshwater fishes. Kottelat, Cornol, Switzerland. 646p.

Kunda, M., M.E. Azim, M.A. Wahab, S. Dewan, N. Roos and S.H. Thilsted 2008. Potential of mixed culture of freshwater prawn (Macrobrachium rosenbergii) and self recruiting small species mola (Amblypharyngodon mola) in rotational rice-fish/ prawn culture systems in Bangladesh. Aquaculture Research 39: 506-517.

Manon, M.R. and M.D. Hossain 2011. Food and feeding habit of Cyprinus carpio var. specularis. J. Sci. Foundation 9: 163-181

Matteson, P.C. 2000. Insect-pest management in tropical Asian irrigated rice fields. Annual Review Entomology 5: 549-574.

Mazid, M.A., B.C. Bakshi, A.K. Das and N. Bari 1992. Fish culture in rice field. FSRDP and BARC, Dhaka.

McComish, T.S. 1967. Food habits of big mouth and small buffalow in Lewis and Cark Lakes and Missouri River. Trans. Am. Fish. Soc. 69: 70-74. 
Md. Mostafizur Rahman Mondol, Md. Mosaddequr Rahman, Dil Afroz Nahar, Ferdous Ahamed, Md. Al-Amin Sarker, Bharat Raj Subba, and Md. Yeamin Hossain/ Our Nature (2013), 11(2): 138-151

McKehni, R.J. and R.B. Penner 1971. Food habits of white Sturgeons, Acipencer transmontanus in San Pablo and Suisan Bays California. California Fish Game 57: 109-212.

Mondol, M.M.R, D.A. Nahar, S. Dewan, M.M. Rahman, S. Jasmine, B.R. Subba and M.Y. Hossain 2013. Food and Feeding Habits of the Mola carplet Amblypharyngodon mola (Hamilton, 1822) in Rice Field Ecosystem with Consideration of Water Quality Parameters. Our Nature 11(1): 61-75.

Nhan, D.K., L.T. Phong, M.J.C. Verdegem, L.T. Duong, R.H. Bosma and D.C. Little 2007. Integrated freshwater aquaculture, crop and livestock production in the Mekong delta, Vietnam: determinants and the role of the pond. Agricultural Systems 94: 445-458.

Sah, G.N., K.L. Sehgal, E. Mitra and A.C. Nandy
1971. Studies on the seasonal and diurna variations in physico-chemical and biological parameters of a freshwater pond. J. Inland Fish. Soc. India 3: 79-102.

Scott, W.B. and E.J. Crossman 1973. Freshwater fishes of Canada. Bull. Fish. Res. Board Can. 184: 1-966.

Stirling, H.P. 1985. Chemical and biological methods of water quality analysis for aquaculturists. Institute of aquaculture, university of Stirling, Scotland. 119p.

Uddin, J.M. 1998. Effects of fish culture on rice fields of rice and nutrients availability in soil, straw and grain. Bangladesh Agricultural University, Mymensingh. 115p. (M.Sc. Thesis)

Whitton, B.A., A. Aziz, P. Francis, J.A. Rother, T.W. Simon and Z.N. Tahmida 1988. Ecology of deep water rice in Bangladesh (Physical and chemical environment). Hydrobiologia 169: 3-67. 